\title{
Interleukin 1 Receptor Antagonist (IL-1Ra) Is an Acute-Phase Protein
}

\author{
Cem Gabay, ${ }^{\star}$ Michael F. Smith, Jr., ${ }^{\ddagger}$ Denise Eidlen, ${ }^{\star}$ and William P. Arend ${ }^{\star}$ \\ *Division of Rheumatology, Department of Medicine, University of Colorado Health Sciences Center, Denver, Colorado 80262; and \\ ${ }^{\ddagger}$ Division of Gastroenterology, Department of Medicine, University of Virginia Health Sciences Center, Charlottesville, Virginia 22906
}

\begin{abstract}
Interleukin 1 receptor antagonist (IL-1Ra) levels are elevated in the blood of patients with a variety of infectious, immune, or traumatic conditions. To examine whether IL1Ra is produced by liver cells with characteristics resembling an acute-phase protein, human primary hepatocytes isolated from liver biopsies and HepG2 hepatoma cells were stimulated with IL-1 $\beta$, IL-6, and TNF $\alpha$. IL-1Ra was present in the supernatants of both cells, with production significantly enhanced by IL-1 $\beta$, and by the combination of IL-1 $\beta$ and IL-6. The term IL-1Ra refers to two different proteins encoded by the same gene, but generated by alternative splicing of two different first exons. One isoform is secreted (17-kD sIL-1Ra), and the other isoform remains in the cytoplasm (18-kD icIL-1Ra). By Western blot analysis, the supernatants of human hepatoma (HepG2) cells contained only sIL-1Ra, whereas the lysates contained a novel smaller molecular mass isoform of $16 \mathrm{kD}$. RT-PCR and ribonuclease protection assay with RNA from HepG 2 cells showed that only SIL-1Ra mRNA was expressed, and confirmed the inducing effect of IL-1 $\beta$ and IL-6. Transfection studies were performed using constructs containing the promoters of either sIL-1Ra or icIL-1Ra coupled to the luciferase reporter gene. The sIL-1Ra promoter was active in HepG 2 cells stimulated by IL-1 $\beta$ and/or IL-6, whereas the icIL-1Ra promoter was inactive. Mutation of binding sites for transcription factors NF- $\kappa \mathrm{B}$ and/or C/EBP within the proximal sIL-1Ra promoter led to significant decreases in response to IL-1 $\beta$ and IL-6 in comparison to the wild-type promoter. Electromobility gel shift assays confirmed the presence of NF- $\kappa \mathrm{B}$ and $\mathrm{C} / \mathrm{EBP}$ binding sites within the sIL-1Ra promoter, and indicated a significant increase in the binding activities of nuclear proteins from HepG 2 cells treated with IL-1 $\beta$ and IL-6. In summary, sIL-1Ra, but not icIL-1Ra, is produced by hepatocytes, and is regulated by proinflammatory cytokines as an acute-phase protein. In addition, NF- $\kappa \mathrm{B}$ and C/EBP family members are likely to play important roles in the full expression of IL-1Ra by hepatocytes during inflammatory conditions. (J. Clin. Invest. 1997. 99:2930-2940.) Key words:
\end{abstract}

This paper was presented at the annual meeting of the International Cytokine Society (October 1996), and at the annual meeting of the American College of Rheumatology (October 1996).

Address correspondence to Dr. Cem Gabay, Division of Rheumatology, University of Colorado Health Sciences Center, Box B-115, 4200 East Ninth Avenue, Denver, CO 80262. Phone: 303-315-5080; FAX: 303-315-5540; E-mail: gabay_c@defiance.uchsc.edu

Received for publication 20 December 1996 and accepted in revised form 7 April 1997.

J. Clin. Invest.

(C) The American Society for Clinical Investigation, Inc.

0021-9738/97/06/2930/11 \$2.00

Volume 99, Number 12, June 1997, 2930-2940 human primary hepatocytes $\cdot$ HepG2 cells • acute-phase response $\cdot \mathrm{NF}-\kappa \mathrm{B} \cdot \mathrm{C} / \mathrm{EBP}$

\section{Introduction}

The acute-phase response refers to a variety of metabolic and biochemical changes that accompany infection, trauma, or immunologically mediated inflammation. The acute-phase proteins (APP), ${ }^{1}$ considered to be the hallmark of the acute-phase response, include a variety of secreted proteins the levels of which are modified during inflammatory conditions (1). These proteins have different biologic functions in maintaining homeostasis. Complement components, many of which are APP, can induce leukocyte chemotaxis (2). C-reactive protein, a major human APP, enhances the elimination of foreign pathogens (3). Other APP, such as $\alpha 1$-antitrypsin and antichymotrypsin, modulate inflammatory events and protect against tissue damage $(4,5)$, whereas fibrinogen plays an important role in tissue repair. APP are produced mainly by hepatocytes in response to several cytokines. Although IL-6 is considered to be the major inducer, other cytokines such IL-1 and tumor necrosis factor (TNF)- $\alpha$ can also stimulate the production of APP (6).

IL-1 plays a key role in inflammation, exerting its effects on a wide variety of cells, and often leading to tissue destruction (7). Interleukin 1 receptor antagonist (IL-1Ra), a naturally occurring antiinflammatory protein, competitively blocks the binding of IL- $1 \alpha$ and IL- $1 \beta$ to type I and type II IL- 1 receptors, but exerts no agonist activity, despite sharing 30\% amino acid sequence homology with IL- $1 \beta$, and $19 \%$ with IL- $1 \alpha(8$, 9). IL-1Ra has been shown to inhibit the effects of IL-1 both in vitro and in vivo, and to reduce the severity of several animal models of inflammatory disease $(10,11)$.

Similar to APP, serum levels of IL-1Ra can rise dramatically during different inflammatory and noninflammatory conditions such as sepsis (12), chronic rheumatic diseases (13-15), and noninflammatory tissue injury (16). Although a variety of cells have been shown to produce IL-1Ra, little is known about the contribution of hepatocytes to circulating IL-1Ra levels during the acute-phase response. Interestingly, serum levels of IL-1Ra were found to correlate with serum IL-6 concentrations in children with juvenile chronic arthritis (17). In addition, administration of either IL-1 or IL- 6 to patients increased the circulating levels of IL-1Ra, suggesting that the production of this cytokine might be regulated as an APP $(18,19)$. The studies reported herein describe the production of IL-1Ra by human hepatocytes as well as some characteristics of its regulation.

1. Abbreviations used in this paper: APP, acute-phase protein; DXM, dexamethasone; EMSA, electrophoretic mobility shift assay; GAPDH, glyceraldehyde phosphate dehydrogenase; HepG2 cells, human hepatoma cells; icIL-1Ra, intracellular interleukin 1 receptor antagonist; Luc, luciferase; SAA, serum amyloid A; sIL-1Ra, secreted interleukin 1 receptor antagonist; WT, wild-type. 


\section{Methods}

Cytokines and lipopolysaccharide. IL-1 $\beta$, IL-6, TNF $\alpha$, and IL-4 were purchased from R \& D Systems, Inc. (Minneapolis, MN); the LPS contamination in each cytokine preparation was $<0.1 \mathrm{ng} / \mu \mathrm{g}$ protein according to the manufacturer. LPS (Escherichia coli 055:B5) was obtained from Difco Laboratories Inc. (Detroit, MI), and dexamethasone (DXM) was purchased from Sigma Chemical Co. (St. Louis, MO).

Cell cultures. Human primary hepatocytes were isolated from surgical liver biopsies as previously described $(20,21)$. In brief, liver explants were taken from three patients undergoing partial hepatectomy: two patients for benign tumor, and one patient for local metastasis of colon adenocarcinoma. Patients were not taking any antiinflammatory medications at the time of surgery. A wedge of macroscopically normal tissue (15-30 g) was perfused in the operating room, using a technique as described for rat hepatocytes (22). The liver biopsy was then incised, and hepatocytes were isolated in RPMI1640 medium (GIBCO BRL, Gaithersburg, MD) supplemented with penicillin, streptomycin, and 10\% FCS (GIBCO BRL). Viable hepatocytes $\left(75 \times 10^{3}\right.$ cells $/ 0.5 \mathrm{ml}$ per well) were seeded on 48 -well culture plates. After $48 \mathrm{~h}$ of culture, the cells were stimulated. Supernatants were collected at $24 \mathrm{~h}$, aliquoted, and kept frozen at $-20^{\circ} \mathrm{C}$ until assayed for IL-1Ra content.

HepG2 (human hepatoma) cells were kindly contributed by Dr. A. Siddiqui (Department of Microbiology, University of Colorado Health Sciences Center, Denver, CO) and cultivated in 24-well plates in DMEM from Mediatech, Inc. (Herndon, VA) supplemented with penicillin, streptomycin, and 10\% FCS from Summit Biotechnology (Greeley, CO). After a 72-h culture, the cells reached confluence, the medium was renewed, and stimulants were added. The supernatants of the cells were collected at different times according to the experimental protocols.

IL-1Ra ELISA. IL-1Ra concentrations were measured in culture supernatants from human primary hepatocytes, and in both supernatants and cell lysates from HepG2 cells. For the quantification of intracellular IL-1Ra, the cells were washed twice with Hanks' balanced salt solution (Mediatech, Inc.), and lysates were generated by adding $1 \mathrm{ml}$ fresh medium to the cells followed by three freeze-thaw cycles. A modification of a previously described sandwich ELISA was used to determine IL-1Ra concentrations (23). The sensitivity of this assay was $78 \mathrm{pg} / \mathrm{ml}$. ELISA was performed in triplicate for each sample of supernatant and lysate.

Western blot analysis. Western blot analyses were performed on cell lysates, and culture supernatants obtained from HepG2 cells cultivated in $60-\mathrm{mm}$ plates. Cell lysates were generated using a lysis buffer containing $0.5 \%$ Nonidet $\mathrm{P}-40$ in $20 \mathrm{mM}$ Tris ( $\mathrm{pH} \mathrm{7.5)}$ ) and the following proteinase inhibitors: $1 \mu \mathrm{g} / \mathrm{ml}$ leupeptin, $1 \mu \mathrm{g} / \mathrm{ml}$ pepstatin, $1 \mathrm{mM}$ PMSF, and $1 \mathrm{mM}$ EDTA. To eliminate the excess of high molecular weight serum proteins from culture supernatants, and to concentrate IL-1Ra, culture supernatants were first centrifuged (Centricon 50 column; Amicon, Inc., Beverly, MA) and then precipitated in $10 \%$ trichloroacetate (TCA) and $0.15 \mathrm{mg} / \mathrm{ml}$ deoxycholate overnight at $4^{\circ} \mathrm{C}$. Cell lysates $(20 \mu \mathrm{g}$ total protein $)$ and TCA-precipitated supernatant proteins were heated in reducing loading buffer, and were electrophoresed on $15 \%$ polyacrylamide gels followed by electrophoretic transfer to PVDF membrane (DuPont-NEN, Boston, MA). Blots were blocked with $10 \%$ nonfat milk in PBS/0.1\% Tween overnight at $4^{\circ} \mathrm{C}$. Blots were then washed in PBS-Tween followed by the addition of anti-IL-1Ra mAb (24) diluted 1:1,000 in blocking buffer for $1 \mathrm{~h}$ at room temperature. The membrane was again washed in $\mathrm{PBS} /$ Tween followed by the addition of goat anti-murine IgG antibodies (Jackson ImmunoResearch Laboratories, Inc., West Grove, PA) diluted 1:2,000 in blocking buffer for $1 \mathrm{~h}$ at room temperature. Bound peroxidase-conjugated antibody was detected using a chemiluminescent method (ECL Western Blotting System; Amersham Corp., Arlington Heights, IL). Autoradiography was performed immediately.

$R T$-PCR of sIL-1Ra and icIL-1Ra mRNA. Total RNA was ob- tained from HepG2 cells cultivated in 100-mm plates. After $20 \mathrm{~h}$ of stimulation, the cells were lysed in $4 \mathrm{M}$ guanidinium isothiocyanate, and RNA was extracted using cesium chloride gradient centrifugation (25). RT-PCR of secreted interleukin 1 receptor antagonist (sIL$1 \mathrm{Ra}$ ), intracellular interleukin 1 receptor antagonist (icIL-1Ra), and glyceraldehyde phosphate dehydrogenase (GAPDH) mRNA was performed as previously described (26). 30 cycles of PCR were performed using the following primers $\left(5^{\prime}\right.$ to $\left.3^{\prime}\right)$ : $5^{\prime}$ sIL-1Ra: GGC CTC CGC AGT CAC CTA ATC ACT CT; 5' icIL-1Ra: CAG GTA CTG CCC GGG TGC TAC TTT AT; 3' common IL-1Ra: TAC TAC TCG TCC TCC TGG AAG TAG AA; 5' GAPDH: AAG GTG AAG GTC AAC G; and 3' GAPDH: CCT TCT CCA TGG TGG TGA AGA C. The amplified products were then electrophoresed within a $1 \%$ agarose gel. The amplified cDNA products of icIL-1Ra, sIL-1Ra, and GAPDH were 577, 521, and 316 bp in size, respectively.

$I L-1 R a$ mRNA quantification by ribonuclease protection assay. Cloning of the coding region of sIL-1Ra cDNA was described previously (24). The sIL-1Ra cDNA was excised from the RSET5a expression plasmid as an Xbal and BamHI fragment, and was cloned in pGEM-7 (Promega Corp., Madison, WI) to generate pRAX/B.GEM. The generation of the GAPDH probe was described previously (21). These plasmids were linearized and transcribed with T3 or SP6 RNA polymerase (Promega) to synthesize the ${ }^{32} \mathrm{P}$-labeled riboprobes complementary to GAPDH and IL-1Ra mRNAs. Both ${ }^{32} \mathrm{P}$-labeled riboprobes were gel-purified, and were resuspended in $5 \times$ hybridization buffer (200 mM Pipes, pH 6.4, $2 \mathrm{M} \mathrm{NaCl}$, and $5 \mathrm{mM}$ EDTA). GAPDH and IL-1Ra mRNAs were analyzed by hybridization of $2 \times 10^{5} \mathrm{cpm}$ of the corresponding riboprobe with $10 \mu \mathrm{g}$ of total RNA. The samples were then digested with $40 \mu \mathrm{g}$ RNase A (Boehringer Mannheim, Mannheim, Germany) and $2 \mu \mathrm{g}$ RNase T1 (Calbiochem Corp., San Diego, CA). After subsequent treatment with $100 \mu \mathrm{g}$ proteinase $\mathrm{K}$ (GIBCO BRL) in the presence of $0.5 \%$ SDS, the protected RNA fragments were extracted with phenol-chloroform, ethanol-precipitated, and resolved on denaturing $6 \%$ polyacrylamide- $8 \mathrm{M}$ urea gels. Autoradiography was then performed. Quantification of IL-1Ra and GAPDH mRNA fragments (191 and $470 \mathrm{bp}$, respectively) were performed by PhosphorImager (Imagequant; Molecular Dynamics Inc., Sunnyvale, CA).

Plasmid constructs. The psRA-1680Luc and picRA-4555Luc refer to the 1,680 bp of 5'-flanking DNA with respect to the first exon of sIL-1Ra, and to the 4,555 bp of $5^{\prime}$-flanking DNA with respect to the first exon of icIL-1Ra, respectively. Both DNA fragments were cloned in the unique HindIII site of pA3Luc, a promoterless luciferase (Luc) expression vector. The results of different in vitro experiments using psRA-1680Luc or picRA-4555Luc have shown that both DNA fragments contain cis-acting DNA elements responsible for cell type-specific expression of sIL-1Ra and icIL-1Ra promoters, respectively $(27,28)$. The presence of one NF-кB DNA-binding element located between -93 and -84 (GGGTATTTCC) within the sIL-1Ra promoter, and the generation of mutations on six nucleotides in this site (GctcgagTCC), was described previously (27). By sequence homology, an incomplete C/EBP DNA-binding site (ATTGCG) was located between -158 and -153 within the sIL-1Ra promoter. To generate mutations at this site, primers M155-146A (ACACTCCATTtactcgaggcGTGGGGTTGA) and M155-146B (the reverse complement to $\mathrm{A}$ ) were used to mutate 10 bases within the sIL-1Ra promoter, creating a unique XhoI restriction site and disrupting the potential $\mathrm{C} / \mathrm{EBP}$ binding site. Reaction 1 was conducted using primer M155-146B, and a primer specific for bases -808 to -792 (GTTCAAAAAAGGTCACACGG). Reaction 2 was conducted using primer M155-146A and a primer specific for the luciferase gene containing a HindIII restriction site. The two PCR products were purified by low melting point agarose electrophoresis, and then equal quantities were mixed and used in a third PCR reaction with the two outside primers. The final PCR product (containing an 808-bp promoter fragment) was digested by KpnI and HindIII, and was cloned in pA3Luc. A fragment of 1,386 bases from the distal end of the 1,680-bp promoter to the KpnI site was then cloned in the 
KpnI site to produce the full-length promoter. Mutations in both NF$\kappa \mathrm{B}$ and $\mathrm{C} / \mathrm{EBP}$ binding sites were also generated using the same approach. The two outside primers were the same as described above. Nucleotide sequences of all clones were confirmed by sequencing (dideoxynucleotide method Sequenase Kit; United States Biochemical Corp., Cleveland, $\mathrm{OH}$ ).

HepG2 transfections. Transfections were performed using a modification of the calcium phosphate method. In brief, $0.5 \times 10^{6} \mathrm{HepG} 2$ cells were seeded in 60-mm dishes in complete medium. After $24 \mathrm{~h}$ of culture, $0.5 \mathrm{ml}$ of calcium phosphate precipitate containing $10 \mu \mathrm{g}$ of plasmid DNA was added to each plate, and cells were incubated at $37^{\circ} \mathrm{C}$ for $4 \mathrm{~h}$. The cells were then subjected to a $15 \%$ glycerol shock for $2 \mathrm{~min}$, and, after $24 \mathrm{~h}$, cytokines were added. The cells were harvested after $18 \mathrm{~h}$ of stimulation, if not otherwise described, and luciferase activity was assessed as described previously (27). In all experiments, luciferase activity was normalized to total protein concentration of the cell lysate as measured (protein assay kit; BioRad Laboratories, Richmond, CA).

Nuclear extracts. Nuclear extracts were prepared from untreated HepG 2 cells, or cells stimulated by IL-1 $\beta$, IL-6, or a combination of both cytokines for $30 \mathrm{~min}$ or $3 \mathrm{~h}$ by a modification of the method of Dignam et al. (29). Nuclei were prepared by lysing the cells in buffer A $(10 \mathrm{mM}$ Hepes, $\mathrm{pH} 7.9,1.5 \mathrm{mM} \mathrm{MgCl} 2,10 \mathrm{mM} \mathrm{KCl}, 0.5 \mathrm{mM}$ DTT, and $0.1 \%$ Triton $\mathrm{X}-100)$. Nuclei were pelleted by centrifugation at $800 \mathrm{~g}$ for $10 \mathrm{~min}$ at $4^{\circ} \mathrm{C}$. Nuclei were then resuspended in buffer $\mathrm{C}(20$ $\mathrm{mM}$ Hepes, $\mathrm{pH} 7.9,25 \%$ glycerol, $0.42 \mathrm{M} \mathrm{NaCl}, 1.5 \mathrm{mM} \mathrm{MgCl}_{2}, 0.2$ $\mathrm{mM}$ EDTA, $0.5 \mathrm{mM}$ PMSF, and $0.5 \mathrm{mM} \mathrm{DTT}$ ), gently rocked at $4^{\circ} \mathrm{C}$ for $30 \mathrm{~min}$, and centrifuged for $30 \mathrm{~min}$ at $4^{\circ} \mathrm{C}$. The supernatant was dialyzed overnight into buffer D (20 mM Hepes, $\mathrm{pH} 7.9,100 \mathrm{mM} \mathrm{KCl}$, $12.5 \mathrm{mM} \mathrm{MgCl} 2,0.1 \mathrm{mM}$ EDTA, $2 \mathrm{mM}$ DTT, and $17 \%$ glycerol), followed by centrifugation at $4^{\circ} \mathrm{C}$ to remove particulate material. Protease and phosphatase inhibitors were added to the buffers, including $1 \mu \mathrm{g} / \mathrm{ml}$ leupeptin, $1 \mu \mathrm{g} / \mathrm{ml}$ aprotinin, $1 \mu \mathrm{g} / \mathrm{ml}$ pepstatin, $10 \mathrm{mM} \beta$-glycerophosphate, and $1 \mathrm{mM}$ sodium vanadate. Protein concentrations were measured using a protein assay kit (Bio-Rad Laboratories). Nuclear proteins were kept at $-80^{\circ} \mathrm{C}$ until used for electrophoretic mobility shift assay (EMSA).

EMSA. For NF-кB, $10 \mu \mathrm{g}$ of nuclear extracts was incubated in 20 $\mu l$ of EMSA-binding reaction consisting of $10 \mathrm{mM}$ Hepes ( $\mathrm{pH} 7.9$ ), 80 $\mathrm{mM} \mathrm{KCl}, 1$ mM EDTA (pH 8.0), 1 mM EGTA (pH 8.0), 6\% glycerol, and $4 \mu \mathrm{g}$ poly (dI:dC) at $15^{\circ} \mathrm{C}$ for 15 min before adding $25,000 \mathrm{cpm}$ of ${ }^{32} \mathrm{P}$-labeled oligonucleotide probe for an additional $15 \mathrm{~min}$ at $15^{\circ} \mathrm{C}$. For C/EBP, the binding reaction was performed with $4 \mu \mathrm{g}$ of nuclear extracts in $40 \mathrm{mM} \mathrm{KCl}, 1 \mathrm{mM}$ EDTA ( $\mathrm{pH} 8.0$ ), $5 \mathrm{mM} \mathrm{MgCl} 2,2.5 \mathrm{mM}$ DDT, and $3 \mu \mathrm{g}$ poly(dI:dC) for $10 \mathrm{~min}$ on ice before adding 50,000 cpm of ${ }^{32} \mathrm{P}$-labeled oligonucleotide probe for an additional $15 \mathrm{~min}$ at room temperature. The reaction was analyzed on a $5 \%(6 \%$ for $\mathrm{C} / \mathrm{EBP})$ nondenaturing polyacrylamide gel in $0.5 \times(0.25 \times$ for $\mathrm{C} / \mathrm{EBP})$ Trisborate/EDTA buffer. After electrophoresis, the gel was fixed in $10 \%$ acetic acid, dried under vacuum, and autoradiography was performed immediately.

For DNA competition studies, the binding reaction was conducted in the presence of nonspecific competitor together with a 100fold molar excess of unlabeled probe. For antibody supershift assays, the extracts were preincubated either with antibodies against the p65 (RelA) subunit of NF-кB, C/EBP $\beta$ (NF-IL6), or C/EBP $\delta$ (NF-IL6 $\beta$ ). Rabbit IgG was used as control. Both antibodies and consensus sequence oligonucleotides were purchased from Santa Cruz Biotechnology (Santa Cruz, CA). Oligonucleotides used in EMSA were as follows: NF-кB wild-type (WT): ATG CGA GGA GGG TAT TTC CGC TTC T; NF-кB mutant: ATG CGA GGA Get cga gTC CGC TTC T; consensus NF-кB: ATG TGA GGG GAC TTT CCC AGG; C/EBP WT: ACA CTC CAT TGC GAC ACT TAG TGG G; C/EBP mutant: ACA CTC CAT Tta ctc gag gcG TGG G; consensus C/EBP: TGC AGA TTG CGC AAT CTG CA; consensus C/EBP mutant: TGC AGA gac tag tcT CTG CA; and C/EBP binding site from serum amyloid A (SAA) promoter: AGC TTC CAT AGG TTA CAC AAC TGG GAT A.
Double-stranded WT oligonucleotides were labeled with [ $\left.{ }^{32} \mathrm{P}\right] \mathrm{dNTPs}$ by fill-in reaction of $5^{\prime}$ overhangs using the Klenow enzyme (Promega Corp.), and were isolated by two passages over Sephadex G-50 spin columns.

Statistical analysis. Student's $t$ test (unpaired, two-tailed) was used for comparisons between specified different conditions.

\section{Results}

IL-1Ra production by human primary hepatocytes. Human primary hepatocytes obtained from surgical biopsies were cultured with different cytokines known to stimulate the production of APP, such as IL-1 $\beta$, IL- 6 and TNF $\alpha$. After $24 \mathrm{~h}$, the presence of IL-1Ra in culture supernatants was examined by ELISA (Fig. 1). The production of IL-1Ra was significantly stimulated by IL- $1 \beta$ or IL- 6 alone, and particularly by the combination of both cytokines. Stimulation of hepatocytes with concentrations of cytokines (IL-1 $\beta$, IL- 6 , or TNF $\alpha$ ) between 0.1 and $10 \mathrm{ng} / \mathrm{ml}$ showed that IL-1 $\beta$ was always the most potent inducer (data not shown). The concentrations of IL-1 $\beta$, IL-6, or TNF $\alpha$ depicted in Fig. 1 gave maximal induction of IL$1 \mathrm{Ra}$ at $24 \mathrm{~h}$.

The human primary hepatocytes stimulated with both IL$1 \beta$ and IL- 6 secreted high levels of sIL-1Ra $\left(\sim 8 \mathrm{ng} / 10^{6}\right.$ cells $)$. These levels are greater than those of sIL-1Ra secreted by LPS-stimulated neutrophils $\left(\sim 0.5 \mathrm{ng} / 10^{6}\right.$ cells $)$, and are comparable to secretion by IgG-stimulated monocytes $(\sim 10 \mathrm{ng} /$ $10^{6}$ cells) or GM-CSF-stimulated alveolar macrophages from nonsmoking donors $\left(\sim 19.5 \mathrm{ng} / 10^{6}\right.$ cells $)(26,30,31)$. These data indicate that hepatocytes are capable of producing large amounts of IL-1Ra, and may represent the major source of IL$1 \mathrm{Ra}$ in the circulation.

IL-1Ra production by HepG2 hepatoma cell line. The production of IL-1Ra by HepG2 cells was next examined; HepG2 is a hepatoma cell line widely used to study the production of APP. HepG2 cells were cultured for $24 \mathrm{~h}$ with the same set of cytokines used in the previous experiments with primary hepa-

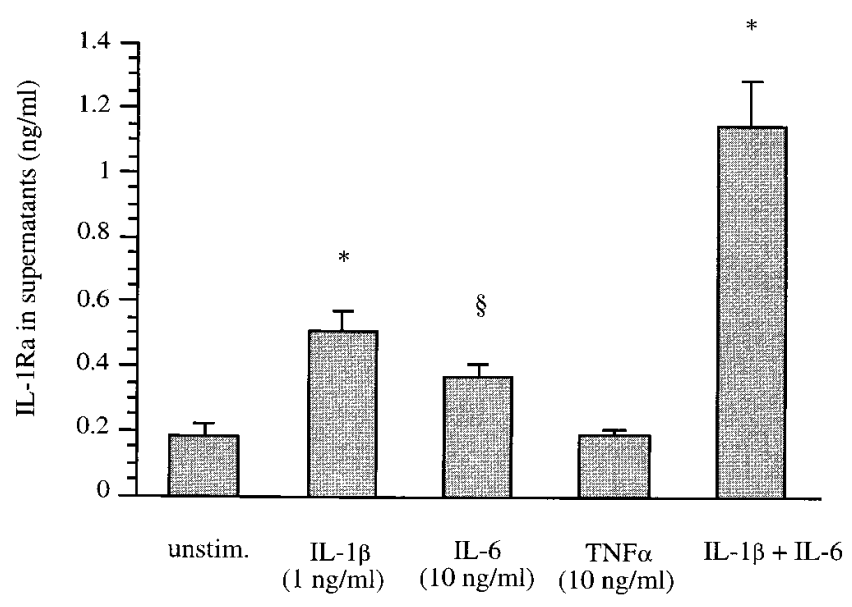

Figure 1. Production of IL-1Ra by human primary hepatocytes. Human primary hepatocytes were cultured in the absence (unstim.) or presence of IL-1 $\beta$, IL- 6 , or TNF $\alpha$ alone, or with a combination of IL$1 \beta$ and IL-6. After $24 \mathrm{~h}$, supernatants were collected, and IL-1Ra concentrations were determined by ELISA. Values represent the mean \pm SD of duplicates from three experiments. ${ }^{*} P<0.0001,{ }^{\S} P<$ 0.01 , in comparison to unstimulated cells. 

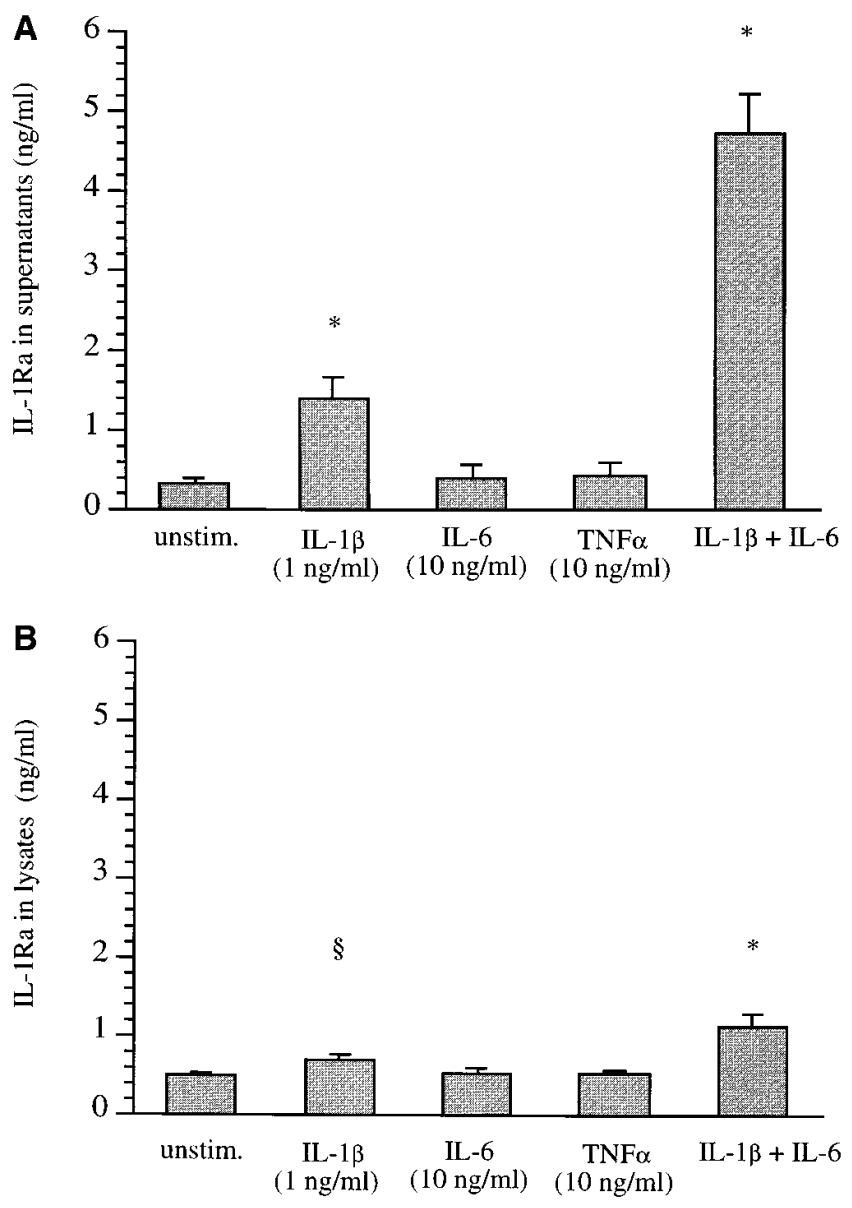

Figure 2. Production of IL-1Ra by the HepG2 hepatoma cell line. HepG2 cells were cultured in the absence (unstim.) or presence of IL-1 $\beta$, IL-6, or TNF $\alpha$ alone, or with a combination of IL-1 $\beta$ and IL-6 for $24 \mathrm{~h}$. Levels of IL-1Ra were measured by ELISA in culture supernatants $(A)$ or in cell lysates $(B)$. Values represent the mean $\pm \mathrm{SD}$ of duplicates from three experiments. ${ }^{*} P<0.0001,{ }^{\S} P<0.05$, in comparison to unstimulated cells.

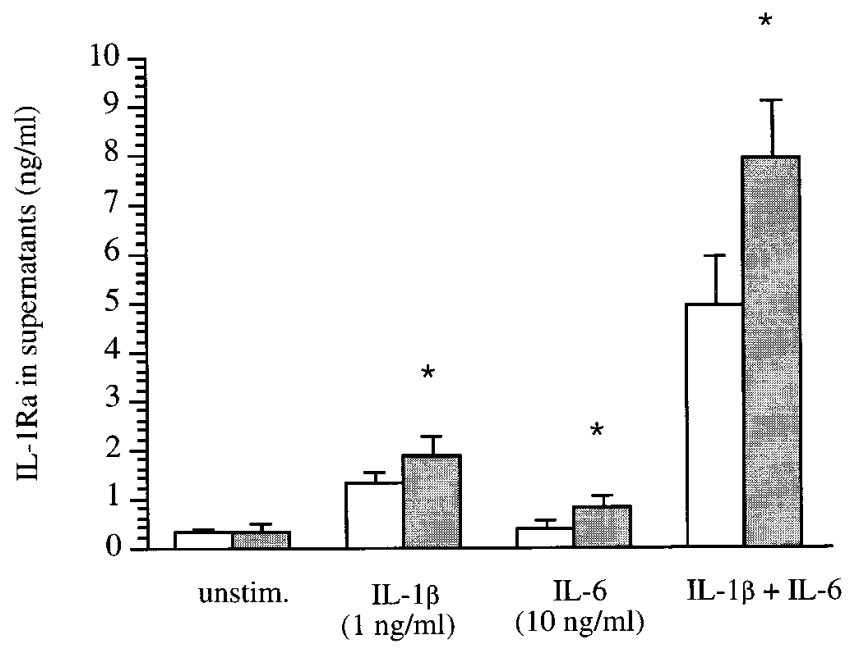

Figure 4. Effect of DXM on IL-1Ra production. Unstimulated (unstim.) or cytokine-stimulated HepG2 cells were cultured in the presence or absence of DXM for $24 \mathrm{~h}$ (gray bars, $10^{-7} \mathrm{M}$ DXM; open bars, no DXM). Values represent the mean \pm SD of duplicates from three experiments. $* P<0.01$ in comparison to cells cultured with cytokine(s) without DXM.

tocytes. Concentrations of cytokines between $100 \mathrm{pg} / \mathrm{ml}$ and $100 \mathrm{ng} / \mathrm{ml}$ showed that IL-1 $\beta$ alone was the most potent inducer of IL-1Ra production (data not shown). The concentration of IL-1Ra in culture supernatants was significantly enhanced by IL- $1 \beta$ alone, and the combination of IL- $1 \beta$ and IL-6 exhibited a strong synergistic effect (Fig. $2 A$ ). Lower concentrations of IL-1Ra were present in cell lysates, although IL-1 $\beta$ and the combination of IL- $1 \beta$ and IL- 6 again stimulated production (Fig. $2 \mathrm{~B}$ ). The results of time course experiments indicated that the synergistic effect of IL- $1 \beta$ and IL- 6 was already present after $4 \mathrm{~h}$ of stimulation, and that IL-1Ra levels continued to increase through $72 \mathrm{~h}$ (Fig. 3).

Glucocorticoids previously have been shown to enhance

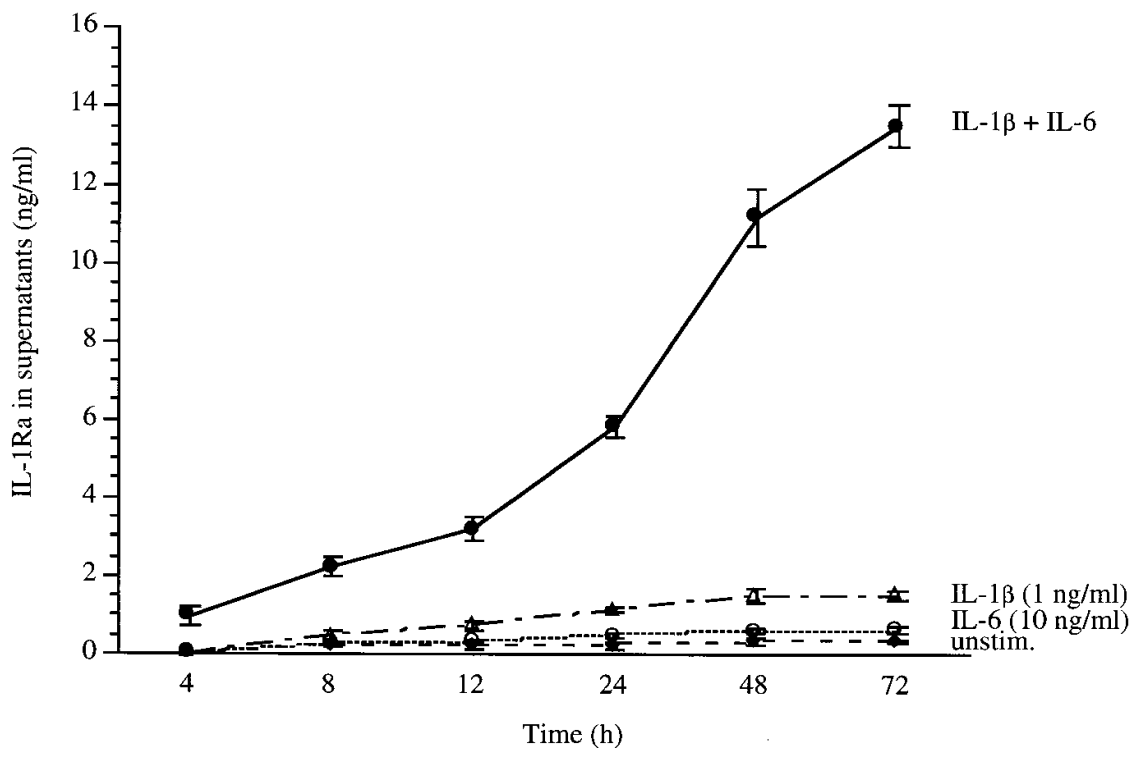

Figure 3. Time course of IL-1Ra production. HepG2 cells were cultured in the absence (unstim.) or presence of IL-1 $\beta$, IL-6, or TNF $\alpha$ alone, or with a combination of IL- $1 \beta$ and IL-6. Culture supernatants were collected at 4 , $8,12,24,48$, and $72 \mathrm{~h}$, and IL-1Ra was measured by ELISA. Values represent mean \pm SD of triplicates from two experiments. 


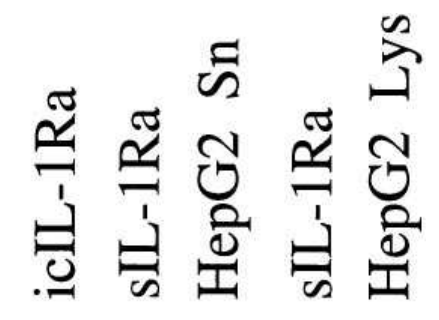

Figure 5. IL-1Ra size forms in HepG2 cell supernatant $(S n)$ and lysate (Lys). HepG2 cells were cultured with both IL-1 $\beta$ and IL- 6 for $24 \mathrm{~h}$, and the supernatant and lysate were electrophoresed on polyacrylamide gel, then transferred to PVDF membrane. Western blot analysis was performed using a monoclonal antibody to human IL-1Ra that recognizes all the described isoforms. Lane 1, recombinant 18-kD icIL-1Ra; lane 2, recombinant unglycosylated 17-kD sIL-1Ra; lane 3, HepG2 cell supernatant; lane 4 , recombinant unglycosylated $17-\mathrm{kD}$ sIL-1Ra; lane 5 , HepG2 cell lysate.

the effects of IL-1 and IL- 6 on production of APP by hepatocytes $(32,33)$. As shown in Fig. 4, DXM, at a concentration usually used to costimulate the production of APP $\left(10^{-7} \mathrm{M}\right)$, significantly enhanced the effects of IL- $1 \beta$ and/or IL-6 on production of IL-1Ra by HepG2 cells, but exerted no effects on unstimulated cells.

IL-1Ra Western blot analysis. The term IL-1Ra refers to at least two proteins that are encoded by the same gene, but are generated by alternative splicing of two different first exons. One form is secreted (17-kD sIL-1Ra), and the other larger form, originally described in epithelial cells, lacks a signal peptide and remains in the cytoplasm (18-kD icIL-1Ra) (34). We examined HepG2 cell supernatants and lysates for the presence of these two forms of IL-1Ra by Western blot analysis. As shown in Fig. 5, the supernatant of HepG2 cells stimulated by both IL- $1 \beta$ and IL- 6 demonstrated the presence of two IL$1 \mathrm{Ra}$ bands. The lower band in the supernatants migrated at the same level as recombinant 17-kD unglycosylated sIL-1Ra, and the upper band migrated as a doublet at a distance of 22-25 $\mathrm{kD}$, consistent with variable degrees of glycosylation of sIL1 Ra protein (Fig. 5, lane 3). After digestion with $\mathrm{N}$-glycanase, this entire 22-25-kD region was no longer present, and all IL1 Ra migrated at $17 \mathrm{kD}$ (data not shown). HepG2 lysates contained only a lower molecular mass band migrating at $16 \mathrm{kD}$ (Fig. 5, lane 5).

RNA analysis by RT-PCR and ribonuclease protection assay. To further examine which isoforms of IL-1Ra were expressed in HepG2 cells, RNA was extracted from cells cultured in the presence or absence of cytokines. RT-PCR was performed with specific primers that amplified either sIL-1Ra or icIL-1Ra mRNA. As shown in Fig. 6, only sIL-1Ra mRNA was detectable in HepG2 cells. In contrast, U937 monocytic cells, used as controls, expressed both isoforms when stimulated with $100 \mathrm{ng} / \mathrm{ml}$ LPS and $100 \mathrm{ng} / \mathrm{ml}$ phorbol myristate acetate (PMA). To quantify the production of sIL-1Ra mRNA by HepG2 cells, ribonuclease protection assays were performed using riboprobes specific for IL-1Ra and GAPDH mRNA (Fig. 7 A). The quantification of the sIL-1Ra- and GAPDH mRNA-protected fragments was performed by PhosphorImager, and levels of IL-1Ra mRNA were normalized to GAPDH (Fig. 7 B). Identical to the protein data, IL-1Ra steady state mRNA levels were increased by IL- $1 \beta$ alone, and

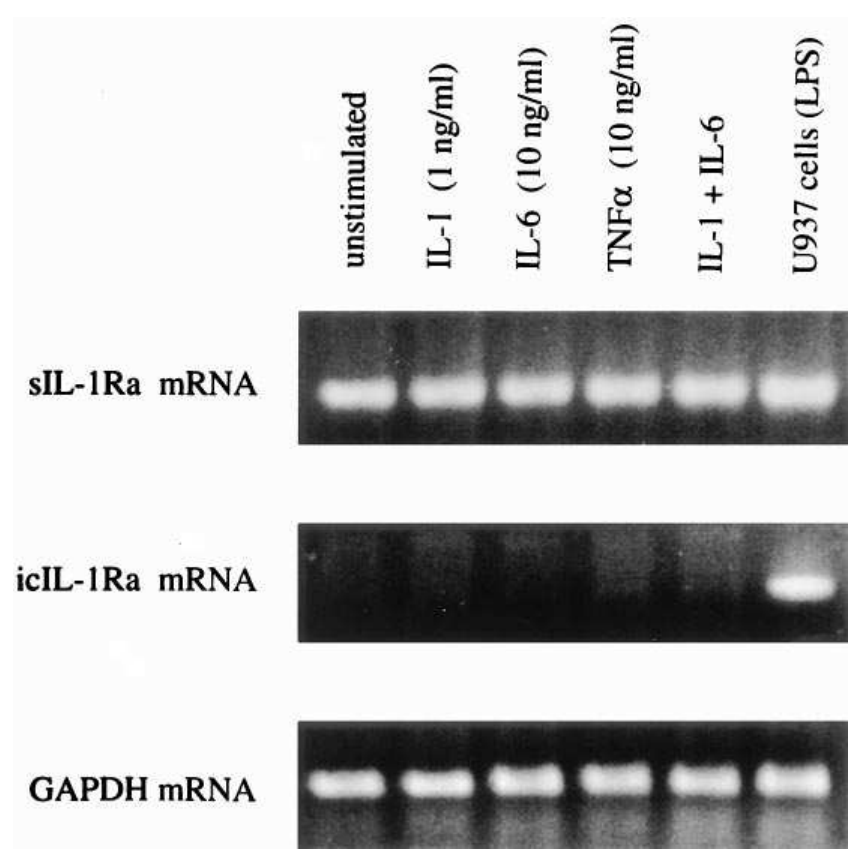

Figure 6. IL-1Ra mRNA isoforms. Total RNA was extracted from HepG2 cells cultured in the absence or presence of IL- $1 \beta$, IL- 6 , or TNF $\alpha$ alone, or with a combination of IL- $1 \beta$ and IL- 6 for $16 \mathrm{~h}$. RNA was also obtained from U937 monocytic cells cultured with $100 \mathrm{ng} / \mathrm{ml}$ LPS and $100 \mathrm{ng} / \mathrm{ml}$ PMA for $16 \mathrm{~h}$. The RNA was reverse-transcribed, then the cDNA was amplified using specific primers for sIL-1Ra, icIL-1Ra, or GAPDH mRNA. RT-PCR products were analyzed by ethidium bromide/agarose gel electrophoresis.

the combination of IL-1 $\beta$ and IL- 6 exhibited an even stronger stimulatory effect.

Transfection studies. Both IL-1Ra isoforms are expressed in distinct cell type-specific patterns. Previous studies, using in vitro gene transfer systems, showed that sIL-1Ra and icIL-1Ra isoforms are regulated by different promoters, and that these promoters controlled reporter gene expression in a manner identical to the endogenous gene $(27,28)$. To examine the response of these two promoters to cytokine stimulation, HepG2 cells were transfected with constructs containing either the 1,680-bp sIL-1Ra (psRA-1680Luc), or the 4,555-bp icIL-1Ra (picRA-4555Luc) promoter regions coupled to the luciferase reporter gene. The results shown in Fig. $8 A$ indicated that the transfected sIL-1Ra promoter was active in HepG2 cells, and was induced strongly by the combination of IL- $1 \beta$ and IL-6, identical to the endogenous gene. In contrast, the icIL-1Ra promoter was inactive in these cells, further indicating that this isoform is not produced by HepG2 cells. To further examine the stimulatory effect of IL-1 $\beta$ and IL-6, the activity of the psRA-1680Luc construct was assessed at different time points. As shown in Fig. 8 , as early as $1 \mathrm{~h}$ after stimulation, the production of luciferase was enhanced by the combination of IL-1 $\beta$ and IL-6. These results further indicate the synergistic response to stimulation with both cytokines, and provide additional evidence confirming that the cloned sIL-1Ra promoter is regulated in a manner consistent with the endogenous gene.

Transcription factors from both NF-kB and C/EBP families have been shown to play key roles in the regulation of APP gene expression. A functional NF- $\mathrm{kB}$ site and a potential 
A

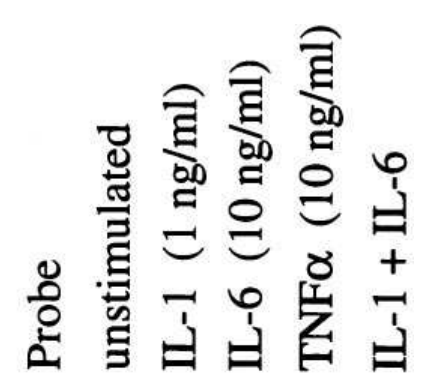

\section{IL-1Ra mRNA}

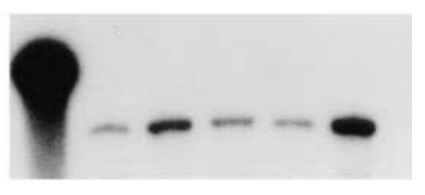

\section{GAPDH mRNA}
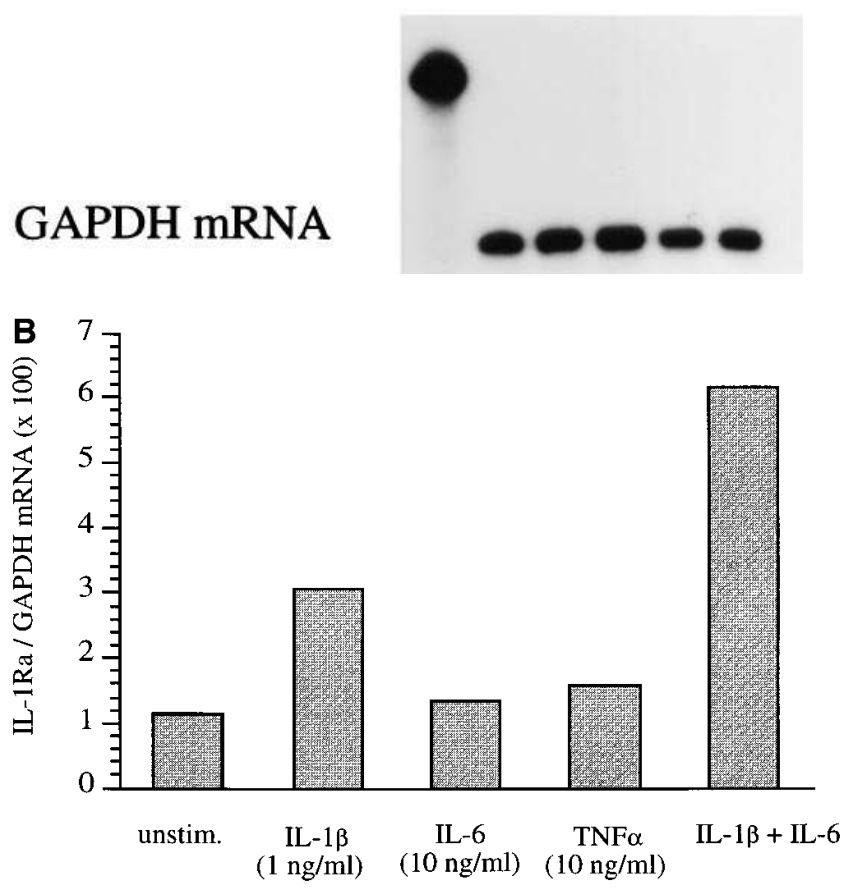

Figure 7. Quantification of IL-1Ra mRNA levels. $(A)$ Total RNA from HepG2 cells cultured in the absence or presence of IL-1 $\beta$, IL-6, or TNF $\alpha$ alone, or with a combination of IL-1 $\beta$ and IL- 6 for $16 \mathrm{~h}$, was analyzed by ribonuclease protection assay. The signals at the left lane represent the undigested probes. $(B)$ Quantitative analysis was performed by PhosphorImager. Results represent IL-1Ra/GAPDH mRNA ratio $\times 100$.

$\mathrm{C} / \mathrm{EBP}$ binding site have been described recently within the sIL-1Ra promoter (27). To examine the roles of these two cisacting DNA regions in sIL-1Ra gene regulation, HepG2 cells were transfected with promoter constructs containing point mutations in the NF- $\mathrm{BB}$ and/or the C/EBP binding sites, and then were stimulated with IL-1 $\beta$ and/or IL-6. As shown in Fig. 9 , the effects of both cytokines alone or in combination were $\sim 50 \%$ decreased using promoter constructs containing mutations in either the NF- $\mathrm{KB}$ or $\mathrm{C} / \mathrm{EBP}$ binding sites. Furthermore, the effects of IL-1 $\beta$ and/or IL- 6 were further decreased
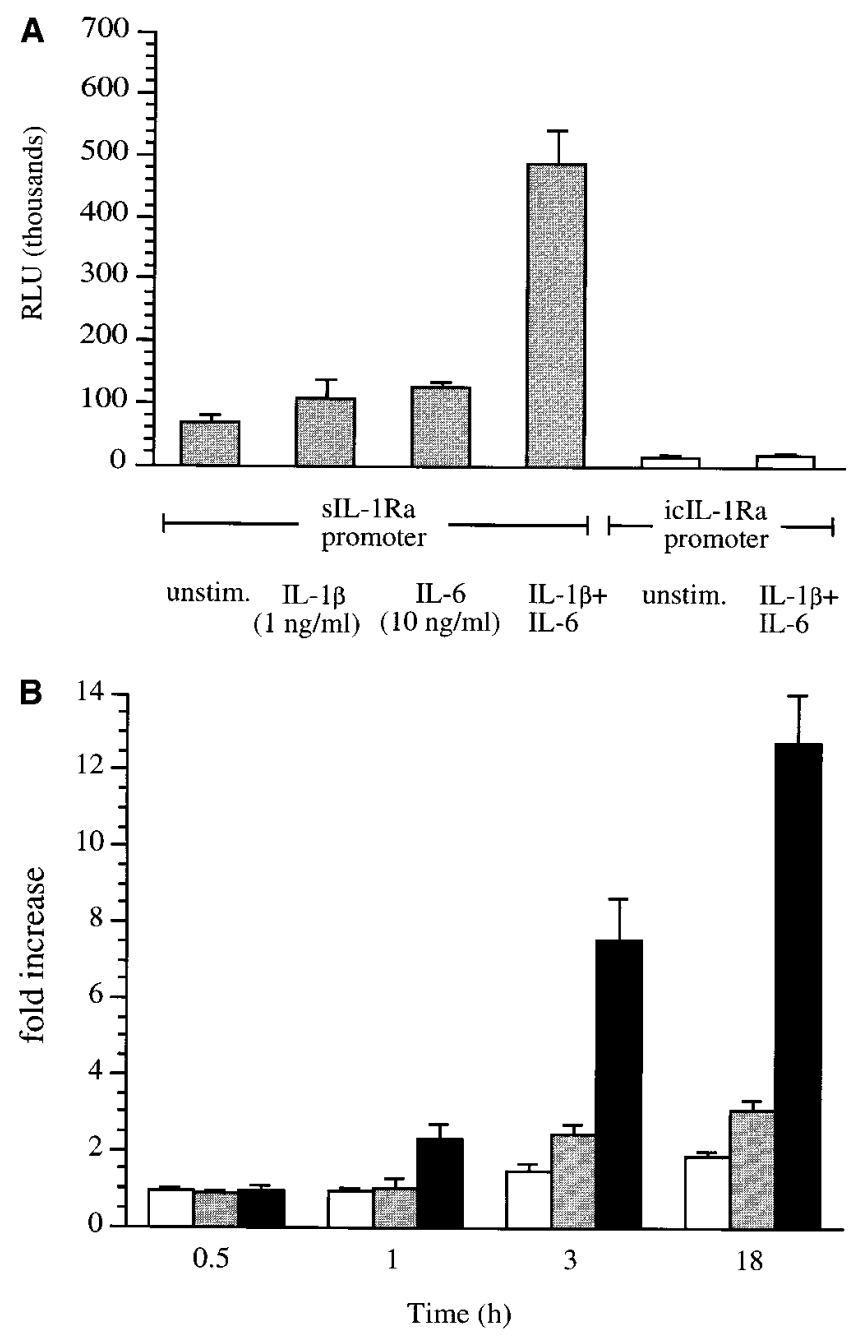

Figure 8. IL-1Ra promoter transfections. (A) HepG2 cells were transfected with constructs containing either the 1,680-bp sIL-1Ra promoter or the 4,555-bp icIL-1Ra promoter coupled to the luciferase reporter gene, then cultured in the absence or presence of IL-1 $\beta$ and/or IL- 6 . After $18 \mathrm{~h}$ of stimulation, cell lysates were assayed for luciferase activity. The luciferase activity was then normalized to total protein concentration. The relative light units $(R L U)$ of psRA1680Luc (solid bars) and picRA-4555Luc (open bars) represent means \pm SEM from four experiments. $(B) \mathrm{HepG} 2$ cells transfected with psRA-1680Luc were cultured in the absence or presence of IL-1 $\beta$ and/or IL-6, and luciferase activity was examined at different time points $(0.5,1,3$, and $18 \mathrm{~h})$. The data are expressed as fold increase over unstimulated cells at each time point. The results represent means \pm SEM from three experiments. White bars, IL-1 $\beta$ (1 ng/ml); gray bars, IL-6 (10 ng/ml); black bars, IL-1 $\beta$ + IL-6.

to almost baseline levels using the sIL-1Ra promoter in which both binding sites were mutated.

EMSA on nuclear extracts. These results indicate that sIL$1 \mathrm{Ra}$ promoter activity induced by IL-1 $\beta$ and IL-6 was decreased markedly in constructs containing point mutations in the NF- $\mathrm{KB}$ binding site, or in the potential C/EBP binding site. Therefore, we determined whether these DNA sequences were able to bind nuclear proteins from HepG2 cells, and if so, whether that binding activity was due to NF-кB and C/EBP proteins. To examine the NF- $\mathrm{B}$ binding activity, a gel retarda- 


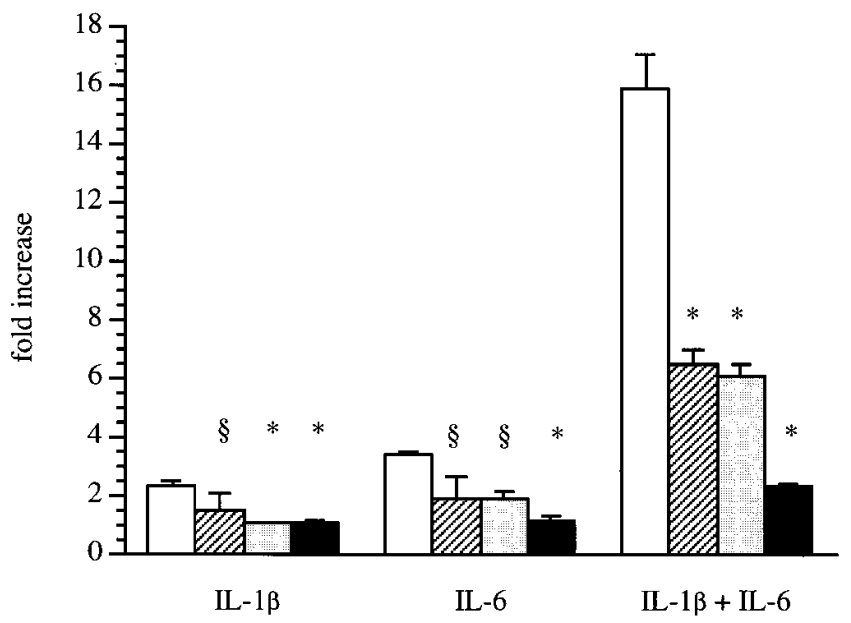

Figure 9. Involvement of NF-кB and/or C/EBP-like binding sites in sIL-1Ra gene transactivation. HepG2 cells were transfected with constructs containing either the wild-type sIL-1Ra promoter (open bars), a mutation in the C/EBP-like binding site (striped bars), a mutation in the NF- $\mathrm{kB}$ binding site (gray bars), or mutations in both binding sites (black bars). The cells were cultured unstimulated, or were stimulated with IL-1 $\beta$ or IL- 6 alone, or with both IL- $1 \beta$ and IL- 6 for $18 \mathrm{~h}$, then harvested and assayed for luciferase activity. Results represent means \pm SEM from three experiments. ${ }^{\S} P<0.05$, $* P<0.001$ in comparison to wild-type promoter.

tion assay was performed using nuclear extracts from HepG2 cells cultured in the presence or absence of IL-1 $\beta$ and/or IL-6 for $30 \mathrm{~min}$. As shown in Fig. 10, unstimulated cells and cells stimulated with IL-6 contained low levels of binding activity to the NF- $\mathrm{KB}$ site (lanes 1 and 3 ). In contrast, treatment with IL$1 \beta$ markedly enhanced the DNA-binding activity (Fig. 10, lane $2)$. Stimulation with both IL-6 and IL-1 $\beta$ produced a pattern similar to IL-1 $\beta$ alone (Fig. 10, lane 4). To characterize further the protein binding to our oligonucleotide, competition studies were performed. The formation of the complex was completely competed away by unlabeled wild-type oligonucleotide, and an oligonucleotide containing the NF- $\mathrm{B}$ consensus region (Fig. 10, lanes 5 and 7), but not by a mutated oligonucleotide (Fig. 10, lane 6). To examine whether the binding activity induced by IL-1 $\beta$ was due to NF- $\mathrm{B}$, immunological reactivity of the complexed protein was tested using an antibody raised against NF-кB p65 (RelA). The results showed the presence of two higher molecular weight bands (supershift) when extracts were pretreated in the presence of antiRelA antibodies (Fig. 10, lane 8). Taken together, these findings indicate that the IL-1 $\beta$-induced binding activity was due to the pres-

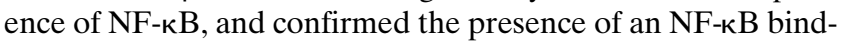
ing site within the sIL-1Ra promoter.

Similar experiments were performed to characterize the potential C/EBP binding site. The nuclear extracts were prepared from HepG2 cells treated with the same set of cytokines, but for a longer period $(3 \mathrm{~h})$. As shown in Fig. $11 A$, incubation of the nuclear extract from HepG2 cells with a probe containing the potential C/EBP site formed multiple DNA-protein complexes. As previously described, this complex pattern is due to the binding of different $\mathrm{C} / \mathrm{EBP}$ family members to the same DNA site (35). Stimulation with IL-1 $\beta$ or IL-6 alone (Fig. $11 A$, lanes 2 and 3 ) did not alter the DNA binding activ-
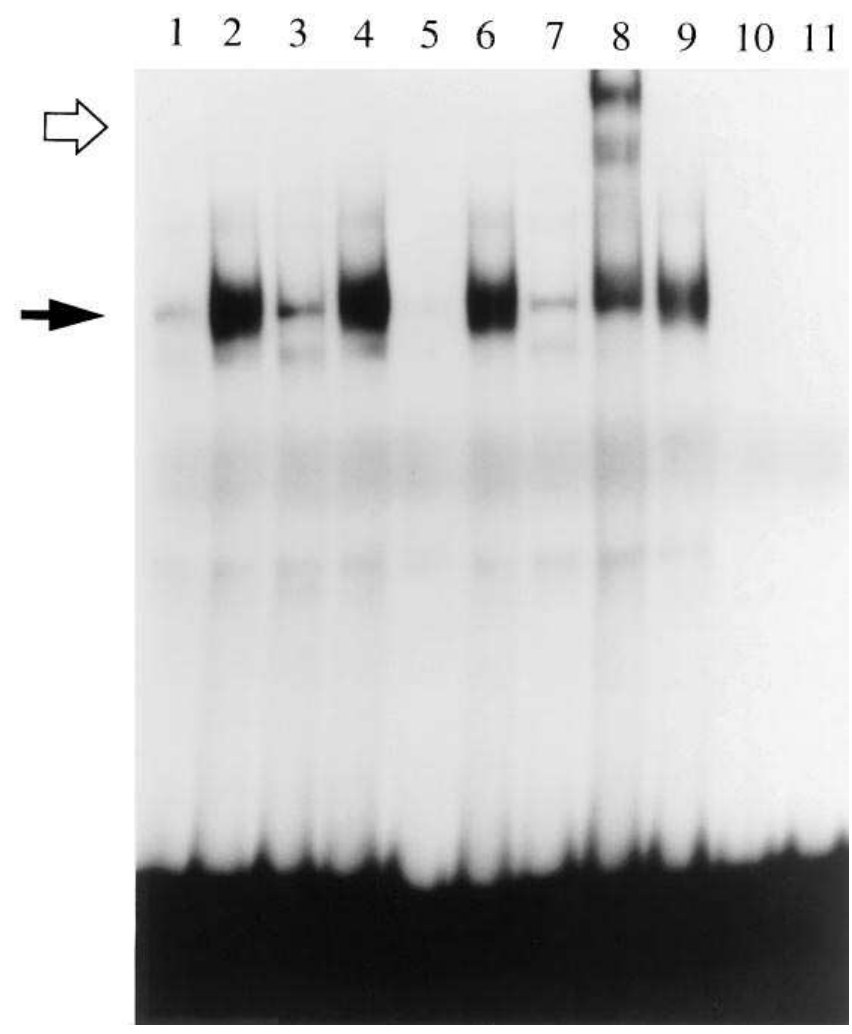

Figure 10. EMSA analysis of NF- $\mathrm{kB}$ binding site. The DNA binding activity of nuclear extracts from HepG2 cells cultured in the presence or absence of IL-1 $\beta$ and/or IL-6 for 30 min was examined using a ${ }^{32} \mathrm{P}$-labeled oligonucleotide from the sIL-1Ra promoter region containing the NF- $\mathrm{kB}$ binding site. Competition studies were performed with nuclear extracts from HepG2 cells stimulated with IL-1 $\beta$ and IL-6 (see Methods). Lane 1, unstimulated; lane 2, IL-1 $\beta$; lane 3, IL-6, lane 4 , IL- $1 \beta$ and IL-6; lane 5, competition with the cold probe; lane 6, competition with the cold probe mutated in the NF-кB binding site; lane 7 , competition with the cold oligonucleotide containing the $\mathrm{NF}-\kappa \mathrm{B}$ consensus region; lane 8 , preincubation of the extracts with antibodies against NF-кB p65 (RelA); lane 9, preincubation with control $\mathrm{IgG}$; lanes 10 and 11 , antip65 antibodies and control $\mathrm{IgG}$ without nuclear extracts. The dark arrow shows the NF-кB-DNA complex. The open arrow represents the supershifted complex.

ity when compared with unstimulated cells (Figure $11 A$, lane $1)$. When IL-1 $\beta$ and IL-6 were used together, however, we observed the appearance of a new protein-DNA complex (Fig. $11 A$, lane 4 ). The results of competition studies indicated that formation of the complex was completely inhibited by a wildtype oligonucleotide (Fig. $11 A$, lane 5), an oligonucleotide containing the $\mathrm{C} / \mathrm{EBP}$ consensus region (Fig. $11 A$, lane 7 ), and an oligonucleotide from the SAA promoter (Fig. 11 $A$, lane 9). There was, however, no inhibition of complex formation by oligonucleotides mutated in the $\mathrm{C} / \mathrm{EBP}$ binding site, or in the C/EBP consensus region (Fig. $11 A$, lanes 6 and 8 ). To determine the origin of the protein within the induced complex, nuclear extracts from cells cultured in the absence or presence of IL-1 $\beta$ and IL- 6 were pretreated with antibodies raised against either $\mathrm{C} / \mathrm{EBP} \beta$ (NF-IL6) or $\mathrm{C} / \mathrm{EBP} \delta$ (NF-IL6 $\beta$ ). As shown in Fig. $11 B$, when using antibodies against $\mathrm{C} / \mathrm{EBP} \delta$, we observed the presence of higher molecular weight bands (supershift) only in nuclear extracts from cells stimulated with both IL-1 $\beta$ 


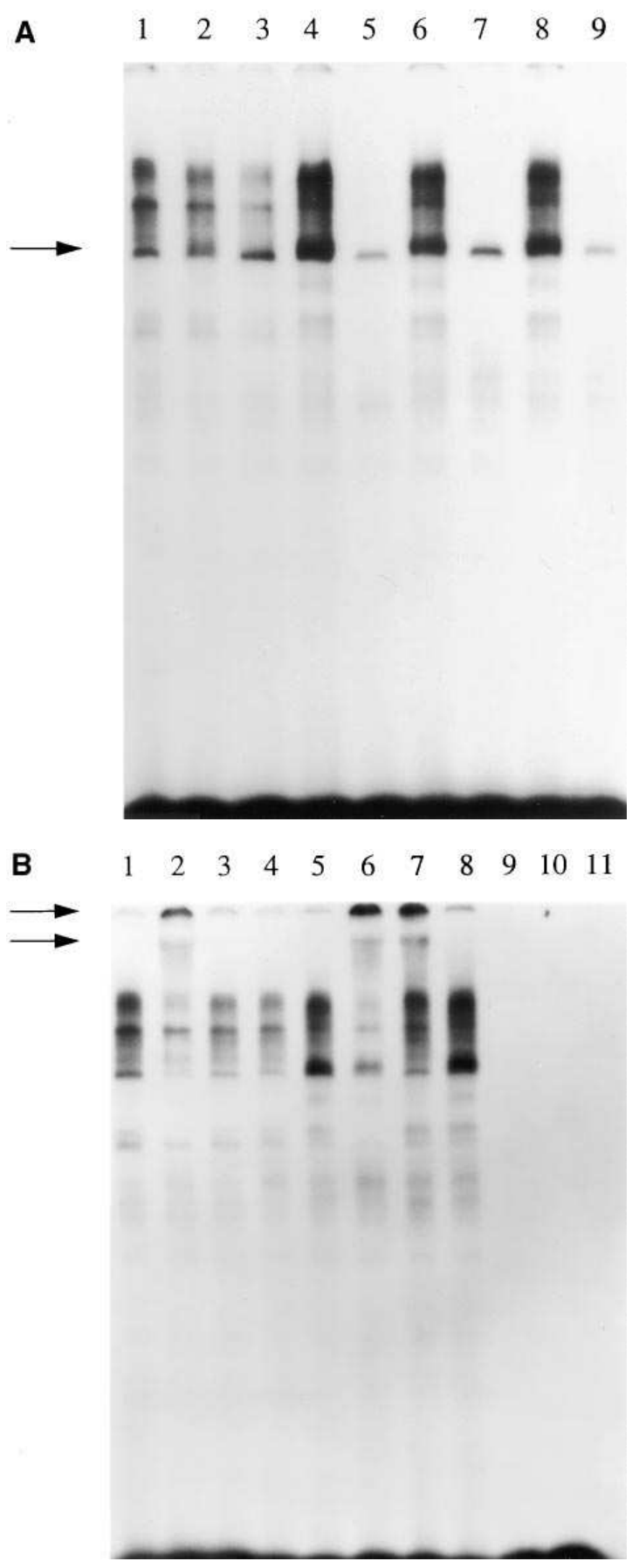

Figure 11. EMSA analysis of C/EBP binding site. $(A)$ The DNA binding activity of nuclear extracts from HepG2 cells cultured in the presence or absence of IL- $1 \beta$ and/or IL- 6 for $3 \mathrm{~h}$ was examined using a ${ }^{32} \mathrm{P}$-labeled oligonucleotide from the sIL-1Ra promoter region containing the potential $\mathrm{C} / \mathrm{EBP}$ binding site. Competition studies were performed with nuclear extracts from $\mathrm{HepG} 2$ cells stimulated with IL-1 $\beta$ and IL-6 (see Methods). Lane 1, unstimulated; lane 2, IL-1 $\beta$; lane 3, IL-6; lane 4, IL-1 $\beta$ and IL-6; lane 5, competition with the cold probe; lane 6 , competition with the cold probe mutated in the potential C/EBP binding site; lane 7, competition with the cold oligonucleotide containing the $\mathrm{C} / \mathrm{EBP}$ consensus region; lane 8 , competition with the cold oligonucleotide containing the mutated C/EBP consensus region; lane 9 , competition with the cold oligonucleotide contain ing the $\mathrm{C} / \mathrm{EBP}$ binding site from the SAA promoter. The arrow indicates the induced protein-DNA complex (lanes 4,6, and 8). (B) The nuclear extracts from unstimulated or IL-1 $\beta$ - and IL-6-stimulated and IL-6. Furthermore, the induced band was removed by treatment with anti-C/EBP $\delta$ antibodies, indicating that $\mathrm{C} / \mathrm{EBP} \delta$ (NF-IL6 $\beta$ ) participated in the induced protein-DNA complex formation (Fig. $11 \mathrm{~B}$, lane 7). Although more faint, the same supershifted band was also present when cells were stimulated with either IL- $1 \beta$ or IL- 6 alone (data not shown). In contrast, and consistent with previous reports showing that $\mathrm{C} / \mathrm{EBP} \beta$ is constitutively expressed in HepG2 cells, supershifted bands were present when nuclear extracts from either unstimulated or stimulated cells were treated with antibodies against $\mathrm{C} / \mathrm{EBP} \beta$ (NF-IL6) (Fig. $11 \mathrm{~B}$, lanes 2 and 6) $(35,36)$. Taken together, these results demonstrate for the first time the presence of a $\mathrm{C} / \mathrm{EBP}$ binding site within the sIL-1Ra promoter, and the role of $\mathrm{C} / \mathrm{EBP}$ family members in the regulation of IL-1Ra production.

\section{Discussion}

APPs are a set of circulating proteins, the levels of which vary during a variety of inflammatory or noninflammatory states, and play critical roles in host defense. The major finding of our studies is that IL-1Ra demonstrates many properties of an APP, providing a unique biologic role for this antiinflammatory protein. The characteristics of IL-1Ra that resemble an APP include elevated serum levels present after inflammation, infection or tissue injury, in vitro production by human primary hepatocytes and HepG2 cells, stimulation of production by IL- $1 \beta$ and IL- 6 both in primary cells and after transfection of promoter constructs into HepG2 cells, DXM-induced enhancement of cytokine-induced IL-1Ra production by HepG2 cells, and regulation of transcription by $\mathrm{NF}-\kappa \mathrm{B}$ and $\mathrm{C} / \mathrm{EBP}$ family members. The effects of IL-1Ra on blocking receptor binding of IL-1 during the acute-phase response may serve to suppress the inflammatory consequences of early IL-1 release.

The IL-1Ra mRNA has been described in HepG2 cells, and IL-1Ra production by hepatocytes was observed during bacteria-induced hepatitis in mice $(37,38)$. The regulation of IL-1Ra production by IL-1 and IL-6 in human primary hepatocytes and HepG2 cells described herein, however, clearly classifies IL-1Ra as an APP. Interestingly, IL-4 and LPS, potent inducers of IL-1Ra production in other cells (39), exerted no effect on the production of IL-1Ra by hepatocytes when examined alone (Gabay, C., unpublished observation).

Elevated circulating levels of glucocorticoids during inflammation, secondary to the stimulation of ACTH by proinflammatory cytokines, are a typical feature of the acute-phase response. The effects of glucocorticoids on IL-1Ra production are variable according to cell type. In monocytes, DXM decreases the LPS-induced synthesis of sIL-1Ra (40), whereas hydrocortisone has been found to induce a small increase in production of icIL-1Ra by keratinocytes (41). Consistent with previous data showing that DXM enhances the production of

HepG2 cells were incubated in the absence (lanes 1 and 5) or presence of antibodies against $\mathrm{C} / \mathrm{EBP} \beta$ (NF-IL6) (lanes 2 and 6 ), $\mathrm{C} / \mathrm{EBP} \delta$ (NF-IL6 $\beta$ ) (lanes 3 and 7), or control IgG (lanes 4 and 8 ) before the addition of the ${ }^{32} \mathrm{P}$-labeled C/EBP probe. Lanes 9-11 contain the $\mathrm{C} / \mathrm{EBP}$ probe and the antibodies against $\mathrm{C} / \mathrm{EBP} \beta$ or $\mathrm{C} / \mathrm{EBP} \delta$, or control $\mathrm{IgG}$, respectively, without nuclear extracts. The arrows indicate the supershifted complexes. 
APP $(32,33)$, our data demonstrate that DXM significantly increased the stimulatory effects of IL- $1 \beta$ and IL- 6 on the production of IL-1Ra by hepatoma cells. Recently published studies indicate that the production of granulocyte colony-stimulating factor was induced by IL-1 $\beta$ in human hepatoma cells, suggesting that other cytokines may also be produced by the liver as APP during inflammatory states (42).

Our data establish that only sIL-1Ra, and not icIL-1Ra, is transcribed in hepatic cells, consistent with the results of earlier studies (37). We also observed, however, the presence of a lower molecular form of IL-1Ra in HepG2 cell lysates. A similar 16-kD intracellular isoform of IL-1Ra has been found recently by our laboratory in neutrophils and monocytes (Malyak, M., unpublished observations). Our data showing that only sIL-1Ra mRNA is expressed in HepG2 cells suggest that this novel isoform is derived from the sIL-1Ra mRNA. As previously observed in supernatants from monocytes cultured on adherent $\operatorname{IgG}$ (43), some unglycosylated sIL-1Ra was present in supernatants from HepG2 cell cultures.

Previous studies with rat and human hepatoma cell lines have shown that APP can be divided into two classes according to the regulatory effects of cytokines on their production. The synthesis of class 1 APP by hepatoma cell lines, including C-reactive protein and SAA protein, is induced by IL-1 and DXM, or by a combination of IL-1, IL-6, and DXM $(32,33$, 44). In contrast, type 2 APPs such as fibrinogen are responsive to IL-6 or IL-6-related cytokines (IL-11, oncostatin-M, leukemia inhibitory factor, ciliary neurotrophic factor) and DXM (45-48). Studies with primary human hepatocytes, however, indicated that IL-6 was the major inducer of all APP production (49). In contrast to results of previous studies with hepatoma cell lines, IL-1 demonstrated no effects on induction of APP production by human primary hepatocytes (20). Our results, using both human primary hepatocytes and hepatoma cells, showed that IL-1Ra production was enhanced by IL-1 $\beta$, and that the combination of IL- $1 \beta$ and IL- 6 had an even stronger effect. To our knowledge, this is the first report describing a protein that behaves as a class 1 APP in both normal hepatocytes and hepatoma cells. The observation that IL- 6 exerted more potent stimulatory effects on primary hepatocytes than on HepG 2 cells could be explained partly by decreased IL-6 responsiveness of tumor cells due to lower levels of IL-6 receptor expression (21).

Our results indicate that both $\mathrm{NF}-\mathrm{kB}$ and $\mathrm{C} / \mathrm{EBP}$ family members are involved in transcription of the sIL-1Ra gene after stimulation with IL-L $\beta$ and IL-6. The transcription factor $\mathrm{NF}-\kappa \mathrm{B}$, a member of the Rel family, binds to $\kappa \mathrm{B}$ enhancer motifs in response to different stimuli such as IL-1 and TNF $\alpha$ (50). The C/EBP family of transcription factors encompasses different members such as $\mathrm{C} / \mathrm{EBP} \alpha, \mathrm{C} / \mathrm{EBP} \beta$ (NF-IL6), and $\mathrm{C} / \mathrm{EBP} \delta$ (NF-IL6 $\beta$ ), that are differentially stimulated during the acute-phase response (51). $\mathrm{C} / \mathrm{EBP} \beta$ and $\mathrm{C} / \mathrm{EBP} \delta$ can bind enhancer elements on APP genes as homodimers or heterodimers, and can upregulate APP gene expression in response to IL-1 and IL-6 $(36,52)$. Using a radiolabeled oligonucleotide containing the $\mathrm{C} / \mathrm{EBP}$ probe from the sIL-1Ra promoter, we showed that $\mathrm{C} / \mathrm{EBP} \beta$ (NF-IL6) is constitutively present in nuclear extracts from HepG2 cells, whereas C/EBPo (NF-IL6 $\beta$ ) is present only when cells are stimulated by IL-1 $\beta$ and IL-6. This finding is in accordance with a previous study indicating that, in Hep3B hepatoma cells, the activity of C/EBP (NFIL6) is enhanced by IL-6 through the modulation of a preexist- ing protein, whereas $\mathrm{C} / \mathrm{EBP} \delta$ (NF-IL6 $\beta$ ) is transcriptionally induced by IL-6 (35).

NF-кB (especially the p65 subunit) and C/EBP $\beta$ cooperatively transactivate the expression of genes that are upregulated during the acute-phase response, such as IL-6, IL-8, and SAA protein $(53,54)$. In addition, accumulating evidence indicates that both $\mathrm{C} / \mathrm{EBP}$ and $\mathrm{NF}-\kappa \mathrm{B}$ binding sites are important in the regulation of genes with expression enhanced during inflammation, including IL-1 $\beta$ (55), TNF $\alpha$, and granulocyte colony-stimulating factor (56). Recently, several investigators have described physical and functional interactions between $\mathrm{C} / \mathrm{EBP}$ and NF-кB family members $(52,57,58)$. These transcription factors directly associate via the b-Zip domain of C/EBP and the Rel homology domain of p65 or p50. In addition, the presence of NF-кB p65 significantly enhanced the binding of $\mathrm{C} / \mathrm{EBP}$ family proteins, such as $\mathrm{C} / \mathrm{EBP} \beta$ and $\mathrm{C} / \mathrm{EBP} \delta$, to their DNA-binding sites (57). Interestingly, we found that IL-6 alone did not significantly alter the formation of C/EBP-DNA complexes. In contrast, when HepG2 cells were stimulated with both IL- 6 and IL- $1 \beta$, the binding activity of nuclear extract was modified with the formation of a new protein-DNA complex including $\mathrm{C} / \mathrm{EBP} \delta$. This finding suggests that NF-кB p65, which is induced by IL- $1 \beta$, may also play an important role in the regulation of IL-1Ra gene expression by enhancing the binding of $\mathrm{C} / \mathrm{EBP} \delta$ to the sIL-1Ra promoter. The interactions between NF- $\mathrm{KB}$ and $\mathrm{C} / \mathrm{EBP}$ transcription factors can therefore explain the synergistic effects of IL-1 and IL- 6 on the production of APPs by hepatocytes, and are likely to participate in the stimulation of IL-1Ra and other APP genes during inflammatory conditions.

\section{Acknowledgments}

We wish to thank Dr. A. Gutierrez-Hartmann (Department of Biochemistry, Department of Biophysics, Department of Genetics, and Department of Medicine, University of Colorado Health Sciences Center, Denver, CO) and Dr. V. Poli (Istituto di Ricerche di Biologia Molecolare [IRBM P. Angeletti], Pomezia, Roma, Italy) for helpful discussions.

C. Gabay is a recipient of a postdoctoral fellowship grant from the Swiss National Foundation for Scientific Research, and from "La Fondation Suisse de Bourse de Medecine et Biologie." This work was supported by National Institutes of Health grants AR-40135 (W.P. Arend) and AI-34358 (M.F. Smith).

\section{References}

1. Kushner, I. 1982. The phenomenon of the acute phase response. Ann. NY Acad. Sci. 389:39-48.

2. Volanakis, J.E., and D.T. Fearon. 1993. The molecular biology of the complement system. In Arthritis and Allied Conditions. Textbook of Rheumatology. D.J. McCarty and W.J. Koopman, editors. Lea and Febiger, Malvern, PA. 455-467.

3. Szalai, A.J., D.E. Briles, and J.E. Volanakis. 1995. Human C-reactive protein is protective against fatal streptococcus pneumoniae infection in transgenic mice. J. Immunol. 155:2557-2563.

4. Kilpatrick, L., L. McCawley, V. Vasanthi, W. Greer, S. Majumdar, H.M. Korchak, and S.D. Douglas. 1992. $\alpha$-1-antichymotrypsin inhibits the NADPH oxidase-enzyme complex in phorbol ester-stimulated neutrophil membranes. $J$. Immunol. 149:3059-3065.

5. Bucurenci, N., D.R. Blake, K. Chidwick, and P.G. Winyard. 1992. Inhibition of neutrophil superoxide production by human plasma alpha-1-antitrypsin. FEBS (Fed. Eur. Biochem. Soc.) Lett. 300:21.

6. Heinrich, P.C., J.V. Castell, and T. Andus. 1990. Interleukin-6 and the acute-phase response. Biochem. J. 265:621-636.

7. Dinarello, C.A. 1996. Biologic basis for interleukin-1 in disease. Blood. 87:2095-2147.

8. Dripps, D.J., B.J. Brandhuber, R.C. Thompson, and S.P. Eisenberg. 1991. 
Interleukin-1 (IL-1) receptor antagonist binds to the $80-\mathrm{kDa}$ IL-1 receptor but does not initiate IL-1 signal transduction. J. Biol. Chem. 266:10331-10336.

9. Granowitz, E.V., B.D. Clarck, J. Mancilla, and C.A. Dinarello. 1991. Interleukin-1 receptor antagonist competitively inhibits the binding of interleukin-1 to the type II interleukin-1 receptor. J. Biol. Chem. 266:14147-14150.

10. Cominelli, F., C.C. Nast, B.D. Clark, R. Schindler, R. Llerena, V.E. Eysselein, R.C. Thompson, and C.A. Dinarello. 1990. Interleukin 1 (IL-1) gene expression, synthesis, and effect of specific IL-1 receptor blockade in rabbit immune complex colitis. J. Clin. Invest. 86:972-980.

11. Wooley, P.H., J.D. Whalen, D.L. Chapman, A.E. Berger, K.A. Richard, D.G. Aspar, and N.D. Staite. 1993. The effect of an interleukin-1 receptor antagonist protein on type II collagen-induced arthritis and antigen-induced arthritis in mice. Arthritis Rheum. 9:1305-1314.

12. Granowitz, E.V., A.A. Santos, D.D. Poutsiaka, J.G. Cannon, D.W. Wilmore, S.M. Wolff, and C.A. Dinarello. 1991. Production of interleukin-1-receptor antagonist during experimental endotoxemia. Lancet. 338:1423-1424.

13. Prieur, A.-M., M.-T. Kaufmann, C. Griscelli, and J.-M. Dayer. 1987. Specific interleukin-1 inhibitor in serum and urine of children with systemic juvenile chronic arthritis. Lancet. 2:1240-1242.

14. Gabay, C., F. Gay-Crosier, P. Roux-Lombard, O. Meyer, P.-A. Guerne, T. Vischer, and J.-M. Dayer. 1994. Elevated serum levels of interleukin-1 receptor antagonist in polymyositis-dermatomyositis: a biological marker of disease activity with a possible role in the lack of acute-phase protein response. Arthritis Rheum. 37:1744-1751.

15. Suzuki, H., H. Takemura, and H. Kashiwagi. 1996. Interleukin-1 receptor antagonist in patients with active systemic lupus erythematosus. Arthritis Rheum. 38:1055-1059.

16. Grzelak, I., W.L. Olszewski, M. Zaleska, M. Durlik, B. Lagiewska, M. Muszynski, and W. Rowinski. 1996. Blood cytokine levels rise even after minor surgical trauma. J. Clin. Immunol. 15:159-164.

17. De Benedetti, F., P. Pignatti, M. Massa, P. Sartirana, A. Ravelli, and A. Martini. 1995. Circulating levels of interleukin $1 \beta$ and of interleukin 1 receptor antagonist in systemic juvenile chronic arthritis. Clin. Exp. Rheumatol. 13:779784 .

18. Bargetzi, M.J., M. Lantz, C.G. Smith, F.M. Torti, I. Olsson, S.P. Eisenberg, and H.F. Starnes, Jr. 1993. Interleukin-1 $\beta$ induces interleukin-1 receptor antagonist and tumor necrosis factor binding protein in humans. Cancer Res. 53:4010-4013.

19. Tilg, H., E. Trehu, M.B. Atkins, C.A. Dinarello, and J.W. Mier. 1994. Interleukin-6 (IL-6) as an anti-inflammatory cytokine: induction of circulating IL-1 receptor antagonist and soluble tumor necrosis factor receptor p55. Blood. 83:113-118.

20. Gabay, C., B. Genin, G. Mentha, P.B. Iynedjian, P. Roux-Lombard, and P.-A. Guerne. 1995. IL-1 receptor antagonist (IL-1Ra) does not inhibit the production of C-reactive protein or serum amyloid A protein by human primary hepatocytes. Differential regulation in normal and tumour cells. Clin. Exp. Immunol. 100:306-313.

21. Gabay, C., P. Silacci, B. Genin, G. Mentha, C. Le Coultre, and P.-A. Guerne. 1995. Soluble interleukin-6 receptor strongly increases the production of acute-phase protein by hepatoma cells but exerts minimal changes on human primary hepatocytes. Eur. J. Immunol. 25:2378-2383.

22. Seglen, P.O. 1976. Preparation of isolated rat liver cells. Methods Cell Biol. 13:29-83.

23. Malyak, M., F.G. Joslin, E.L. Verderber, S.P. Eisenberg, and W.P. Arend. 1993. IL-1Ra ELISA: reduction and alkylation of synovial fluid eliminates interference by IgM rheumatoid factors. J. Immunol. Methods. 36:781789

24. Arend, W.P., M. Malyak, M.F. Smith, Jr., T.D. Whisenand, J.L. Slack, J.E. Sims, J.G. Giri, and S.K. Dower. 1994. Binding of IL-1 $\alpha$, IL-1 $\beta$, and IL-1 receptor antagonist by soluble IL-1 receptors and levels of soluble IL-1 receptors in synovial fluids. J. Immunol. 153:4766-4774.

25. Chirgwin, J.M., A.E. Przybyla, R.J. MacDonald, and W.J. Rutter. 1979. Isolation of biologically active ribonucleic acid from sources enriched in ribonuclease. Biochemistry. 18:5294-5299.

26. Malyak, M., M.F. Smith, Jr., A.A. Abel, and W.P. Arend. 1994. Peripheral blood neutrophil production of interleukin-1 receptor antagonist and interleukin-1ß. J. Clin. Immunol. 14:20-30.

27. Smith, M.F., Jr., D. Eidlen, W.P. Arend, and A. Gutierrez-Hartmann. 1994. LPS-induced expression of the human IL-1 receptor antagonist gene is controlled by multiple interacting promoter elements. J. Immunol. 153:35843593.

28. Jenkins, J.K., R.F. Drong, M.E. Shuck, M.J. Bienkowski, J.L. Slightom, W.P. Arend, and M.F. Smith, Jr. 1997. Intracellular interleukin-1 receptor antagonist promoter: cell type-specific and inducible regulatory regions. J. Immunol. $158: 748-755$.

29. Dignam, J.D., R.M. Lebovitz, and R.G. Roeder. 1983. Accurate transcription initiation by RNA polymerase II in a soluble extract from isolated mammalian nuclei. Nucleic Acids Res. 11:1475-1489.

30. Jenkins, J.K., and W.P. Arend. 1993. Interleukin 1 receptor antagonist production in human monocytes is induced by IL-1 $\alpha$, IL-3, IL-4 and GM-CSF. Cytokine. 5:407-415.

31. Janson, R.W., T.E. King, K.R. Hance, and W.P. Arend. 1993. Enhanced production of IL-1 receptor antagonist by alveolar macrophages from patients with interstitial lung disease. Am. Rev. Respir. Dis. 148:495-503.

32. Baumann, H., and J. Gauldie. 1990. Regulation of hepatic acute phase plasma protein genes by hepatocyte stimulating factors and other mediators of inflammation. Mol. Biol. Med. 7:147-160.

33. Baumann, H., K.R. Prowse, S. Marinkovic, K.-A. Won, and G.P. Jahreis. 1989. Stimulation of hepatic acute phase response by cytokines and glucocorticoids. Ann. NY Acad. Sci. 557:280-295.

34. Haskill, S., G. Martin, L. van Le, J. Morris, A. Peace, C.F. Bigler, G.J. Jaffe, C. Hammerberg, S.A. Sporn, S. Fong, et al. 1991. cDNA cloning of an intracellular form of the human interleukin 1 receptor antagonist associated with epithelium. Proc. Natl. Acad. Sci. USA. 88:3681-3685.

35. Ramji, D.P., A. Vitelli, F. Tronche, R. Cortese, and G. Ciliberto. 1993. The two C/EBP isoforms, IL-6DBP/NF-IL6 and C/EBP $\delta / N F-I L 6 \beta$, are induced by IL- 6 to promote acute phase gene transcription via different mechanisms. Nucleic Acids Res. 21:289-294.

36. Akira, S., H. Isshiki, T. Sugita, O. Tanabe, S. Kinoshita, Y. Nishio, T. Nakajima, T. Hirano, and T. Kishimoto. 1990. A nuclear factor for IL-6 expression (NF-IL6) is a member of a C/EBP family. EMBO (Eur. Mol. Biol. Organ.) J. 9:1897-1906.

37. Steinkasserer, A., C. Estaller, E.H. Weiss, and R.B. Sim. 1992. Human interleukin-1 receptor antagonist is expressed in liver. FEBS (Fed. Eur. Biochem. Soc.) Lett. 310:60-62.

38. Fujioka, N., N. Mukaida, A. Harada, M. Akiyama, T. Kasahara, K. Kuno, A. Ooi, M. Mai, and K. Matsushima. 1995. Preparation of specific antibodies against murine IL-1ra and the establishment of IL-1ra as an endogenous regulator of bacteria-induced fulminant hepatitis in mice. J. Leukocyte Biol. 58: 90-98.

39. Vannier, E., L.C. Miller, and C.A. Dinarello. 1992. Coordinated antiinflammatory effects of interleukin 4: interleukin 4 suppresses interleukin 1 production but up-regulates gene expression and synthesis of interleukin 1 receptor antagonist. Proc. Natl. Acad. Sci. USA. 89:4076-4080.

40. Brown, E.A., H.A. Dare, C.B. Marsh, and M.D. Wewers. 1996. The combination of endotoxin and dexamethasone induces type II interleukin 1 receptor (IL-1r II) in monocytes: a comparison to interleukin $1 \beta$ (IL-1 $\beta$ ) and interleukin 1 receptor antagonist (IL-1ra). Cytokine. 8:828-836.

41. Phillips, W.G., M. Feldmann, S.M. Breathnach, and F.M. Brennan. 1995. Modulation of the IL-1 cytokine network in keratinocytes by intracellular IL-1 $\alpha$ and IL-1 receptor antagonist. Clin. Exp. Immunol. 101:177-182.

42. Lai, Ch.-F., and H. Baumann. 1996. Interleukin-1ß induces production of granulocyte colony-stimulating factor in human hepatoma cells. Blood. 87: 4143-4148.

43. Hannum, C.H., C.J. Wilcox, W.P. Arend, F.G. Joslin, D.J. Dripps, P.L. Heimdal, L.G. Armes, A. Sommer, S.P. Eisenberg, and R.C. Thompson. 1990 Interleukin-1 receptor antagonist activity of a human interleukin-1 inhibitor. Nature (Lond.). 343:336-340.

44. Ganapathi, M.K., D. Rzewnicki, D. Samols, S.-L. Jiang, and I. Kushner. 1991. Effect of combinations of cytokines and hormones on synthesis of serum amyloid A and C-reactive protein in Hep 3B cells. J. Immunol. 147:1261-1265.

45. Baumann, H., and P. Schendel. 1991. Interleukin-11 regulates the hepatic expression of the same plasma protein genes as interleukin-6. J. Biol. Chem. 30:20424-20427.

46. Baumann, H., and G.G. Wong. 1989. Hepatocyte-stimulating factor III shares structural and functional identity with leukemia-inhibitory factor. J. Immunol. 143:1163-1167.

47. Richards, C., T.J. Brown, M. Shoyab, H. Baumann, and J. Gauldie. 1992. Recombinant oncostatin M stimulates the production of acute phase proteins in HepG2 cells and rat primary hepatocytes in vitro. J. Immunol. 148: 1731-1736.

48. Schooltink, H., T. Stoyan, E. Roeb, P.C. Heinrich, and S. Rose-John. 1992. Ciliary neurotrophic factor induces acute-phase protein expression in hepatocytes. FEBS (Fed. Eur. Biochem. Soc.) Lett. 314:280-284.

49. Castell, J.V., M.J. Gomez-Lechon, M. David, T. Andus, T. Geiger, R. Trullenque, R. Fabra, and P.C. Heinrich. 1989. Interleukin-6 is the major regulator of acute phase protein synthesis in adult human hepatocytes. FEBS (Fed. Eur. Biochem. Soc.) Lett. 242:237-239.

50. Osborn, L., S. Kunkel, and G.J. Nabel. 1989. Tumor necrosis factor $\alpha$ and interleukin 1 stimulate the human immunodeficiency virus enhancer by activation of the nuclear factor кB. Proc. Natl. Acad. Sci. USA. 86:2336-2340.

51. Alam, T., M.R. An, and J. Papaconstantinou. 1992. Differential expression of three C/EBP isoforms in multiple tissues during acute phase response. $J$. Biol. Chem. 267:5021-5024.

52. Kinoshita, S., S. Akira, and T. Kishimoto. 1992. A member of the C/EBP family, NF-IL6B, forms a heterodimer and transcriptionally synergizes with NF-IL6. Proc. Natl. Acad. Sci. USA. 89:1473-1476.

53. Matsusaka, T., K. Fujikawa, Y. Nishio, N. Mukaida, K. Matsushima, T. Kishimoto, and S. Akira. 1993. Transcription factors NF-IL6 and NF-кB synergistically activate transcription of the inflammatory cytokines, interleukin 6 and interleukin 8. Proc. Natl. Acad. Sci. USA. 90:10193-10197.

54. Betts, J.C., JK Cheshire, S. Akira, T. Kishimoto, and P. Woo. 1993. The role of NF-кB and NF-IL6 transactivating factors in the synergistic activation of human serum amyloid A gene expression by interleukin-1 and interleu- 
kin-6. J. Biol. Chem. 268:25624-25631.

55. Shirakawa, F., K. Saito, C.A. Bonagura, D.L. Galson, M.J. Fenton, A.C.

Webb, and P.E. Auron. 1993. The human prointerleukin $1 \beta$ gene requires DNA sequences both proximal and distal to the transcription start site for tissue-specific induction. Mol. Cell. Biol. 13:1332-1344.

56. Natsuka, S., S. Akira, Y. Nishio, S. Hashimoto, T. Sugita, H. Isshiki, and T. Kishimoto. 1992. Macrophage differentiation-specific expression of NF-IL6, a transcription factor for interleukin-6. Blood. 79:460-466.

57. Stein, B., P.C. Cogswell, and A.S. Baldwin, Jr. 1993. Functional and physical associations between NF- $\mathrm{BB}$ and $\mathrm{C} / \mathrm{EBP}$ family members: a rel domain-bZIP interaction. Mol. Cell. Biol. 13:3964-3974.

58. LeClair, K.P., M.A. Blanar, and P.A. Sharp. 1992. The p50 subunit of NF-кB associates with the NF-IL6 transcription factor. Proc. Natl. Acad. Sci. USA. 89:8145-8149. 